\title{
Michel Foucault e a Escola de Frankfurt: Reflexóes a Partir da Obra Crítica do PODER, DE AXEL HONNETH ${ }^{1}$
}

\author{
Leomir Cardoso Hilárioº \\ Eduardo Leal Cunha ${ }^{3}$
}

RESUMO: O objetivo deste artigo é analisar os elementos centrais da crítica realizada por Axel Honneth ao pensamento de Michel Foucault, em Crítica do Poder, articulando-a com sua análise da obra do chamado "círculo interno" da Escola de Frankfurt, principalmente Adorno e Horkheimer. Dessa maneira, entende-se que Honneth opera uma aproximação do pensamento foucaultiano à tradição crítica frankfurtiana, com ênfase em deficiências comuns que apontam para uma filiação entre os autores e, ao mesmo tempo, para sua insuficiência na análise da sociedade contemporânea. Tal leitura, contudo, em que pese sua inovação em pôr lado a lado Foucault e Habermas enquanto desenvolvimentos rivais da Teoria Crítica, é limitada tanto cronologicamente, por não levar em consideração a reorientação realizada por Foucault, a partir de 1978, quanto por identificar problematicamente as noçôes de poder e dominação. Essa limitaçấo nấo inviabiliza, entretanto, manter o gesto de convergência entre o pensamento foucaultiano e a Escola de Frankfurt, pensando-o através de uma via positiva, que não se restrinja às limitaçóes das suas ferramentas críticas, mas que, ao contrário, ao focalizar a radicalidade de tal crítica, torne possível destacar a sua atualidade.

PALAVRAS-CHAVE: Foucault. Honneth. Escola de Frankfurt. Crítica do Poder.

Este artigo procura expor e discutir os elementos centrais da crítica realizada por Honneth ao pensamento de Michel Foucault, visando ao

1 Esta pesquisa contou com o apoio da Fapitec/SE e da CAPES, através do programa PROCAD/NF.

${ }^{2}$ Mestrando em Psicologia Social pela Universidade Federal de Sergipe. E-mail: leomirhilario@yahoo. com.br

${ }^{3}$ Doutor em Saúde Coletiva (IMS/UERJ), Professor do Núcleo de Pós-Graduação em Psicologia Social e do Departamento de Psicologia da Universidade Federal de Sergipe. E-mail: dudalealc@uol. com.br 
tema da vinculação entre este e a primeira geração da Escola de Frankfurt, especificamente Adorno e Horkheimer. Para esse fim, partimos do livro Critica do poder ${ }^{4}$ (Kritik der Macht: Reflexionsstufen einer kritischen Gesellschaftstheorie), tese de doutoramento de Axel Honneth, no qual se defende a pertença de Foucault à matriz filosófica frankfurtiana. Nosso foco é, portanto, a avaliação, feita por Honneth, do pensamento de Foucault e sua proposta de inscrição deste na teoria crítica.

Em primeiro lugar, procuraremos esboçar de que maneira, a partir da noção de déficit sociológico, a crítica de Honneth a Foucault se vincula à crítica que ele faz a Adorno e Horkheimer. Para fundamentar esse ponto de vista, utilizaremos dois textos: o primeiro capítulo de Crítica do Poder, intitulado $A$ ideia original de Horkheimer: o déficit sociológico da Teoria Crítica, e o artigo Teoria Crítica, escrito como forma de apresentação das ideias da Escola de Frankfurt e cuja reflexão está centrada em como o próprio Honneth concebe a primeira geração e seus respectivos problemas, deixando claro quais são os eixos de análise que se póem como matéria-prima para a crítica ao pensamento de Foucault.

Em ambos os textos, o argumento central de Honneth é que existe um déficit sociológico nas análises da primeira geração da Escola de Frankfurt, na medida em que descrevem a sociedade como um sistema no qual há, de um lado, as estruturas econômicas e seus imperativos e, de outro, o processo de socialização do indivíduo, sem considerar nenhum ponto de mediação, nem levar em conta a ação social ou a experiência dos próprios indivíduos, nos processos de dominação. Este déficit faria com que Adorno e Horkheimer empreendessem suas análises num "nível funcionalista", ou seja, entendessem, por exemplo, as dimensôes da cultura e da socialização como tendo unicamente por finalidade a imposição do imperativo capitalista de "valorizaçáo do valor", para usar uma expressão de Marx (1988, p. 125).

Essa ideia de funcionalismo ou de nível funcionalista de análise, que será, em seguida, um dos eixos da crítica de Honneth a Foucault, é, ainda em relação à primeira geração da Escola de Frankfurt e mais diretamente a Adorno e Horkheimer, a base para outros desenvolvimentos críticos que apontam

\footnotetext{
${ }^{4}$ Utilizaremos a versão traduzida para o espanhol, cujo título é Crítica del poder: fases en la reflexión de una Teoria Crítica de la sociedad, traduzida por Germán Cano, publicada em 2009 pela Machado Libros. Em alguns momentos, para ajudar na traduçáo dos trechos que citamos, usaremos também a edição americana, The Critique of Power: reflective stages in a critical social theory, traduzida por Kenneth Baynes, publicada em 1991 pela MIT Press.
} 
para: a presença de um reducionismo funcionalista do processo histórico; a centralidade do paradigma da dominaçáo da natureza que compreende apenas uma modalidade de ação social; e, por fim, a insuficiência em considerar as realizações progressistas devido a uma crítica radical da razão.

Após expor os pontos centrais da crítica de Honneth a Adorno e Horkheimer, focalizaremos a obra Crítica do Poder, em especial o capítulo 6, intitulado "A teoria da sociedade de Foucault: uma dissolução teóricosistêmica da Dialética do Esclarecimento". A crítica aí esboçada tem como alvo especificamente o período genealógico de Foucault, cronologicamente situado de meados de 1968 até 1976, aproximadamente, no qual o tema central são as relaçôes poder-saber. Para Honneth, Foucault enfrentaria, através daquilo que compreende como dissolução teórico-sistêmica da obra de Adorno e Horkheimer, as mesmas dificuldades destes.

Dessa maneira, explicitaremos as deficiências em comum destacadas por Honneth, quais sejam: o funcionalismo orientado historicamente, a relação entre poder e coerção vista a partir de uma espécie de behaviorismo e a desvalorização da ordem jurídica face ao processo de intensificação sistêmica do poder. É importante ressaltar como, principalmente no que se refere a este último ponto, Honneth está muito próximo das formulações da chamada "segunda geraçáo" da Escola de Frankfurt, sobretudo quanto ao diagnóstico do presente divergente a propósito da "primeira geração": a introdução de um elemento contraditório no processo histórico da modernidade, visto não apenas como oriundo de um processo subjacente de racionalização, mas também como possuidor de uma dimensão comunicativa, orientada para o consenso. Há, nesse particular, tanto em Honneth quanto em Habermas, a necessidade de revisar os parâmetros da teoria crítica, particularmente na direção da Dialética do Esclarecimento, em que o pensamento correria o risco de se perder na própria possibilidade da crítica e da emancipação.

Por fim, lançaremos interrogaçôes sobre a crítica de Honneth para problematizá-la, principalmente naquilo que diz respeito à identidade entre poder e dominação e aos limites da leitura empreendida por Honneth em relação ao conjunto da obra de Foucault e a seu projeto filosófico, em especial no que concerne aos textos posteriores a 1978, inclusive aqueles marcados de forma mais direta pelo confronto entre seu pensamento e o de Habermas.

Nosso objetivo é manter o gesto iniciado por Honneth de convergência entre o pensamento foucaultiano e a Escola de Frankfurt, porém, buscando 
pensar essa vinculação através de uma via positiva, isto é, que não se restrinja às limitaçóes das suas ferramentas críticas, mas que, ao contrário, ao focalizar a radicalidade de tal crítica, torne possível destacar a sua atualidade. Nesse sentido, as formulaçóes foucaultianas surgem como possibilidades de atualização da crítica empreendida por Adorno e Horkheimer.

\section{O DÉFICIT SOCIOLÓGICO}

Em entrevista a Marcos Nobre e Luiz Repa, questionado sobre o que seria essa deficiência, Honneth (2003) expóe que, em Adorno e Horkheimer, a teoria da sociedade subestima o sentido próprio do mundo da vida social, não atribuindo, dessa maneira, às normas morais nem às operações interpretativas dos sujeitos papel essencial na reprodução da sociedade. Assim, ambos tenderiam a um "funcionalismo marxista", ou seja, a socialização, a integração cultural e o controle jurídico teriam apenas como funçáo a imposição do imperativo capitalista da valorizaçãos.

A ideia de "funcionalismo" refere-se sobretudo ao modo como esses autores negligenciariam uma esfera intermediária entre os imperativos que produzem dominaçáo social e os valores morais, bem como a socialização dos indivíduos. Nessa perspectiva, procuraremos demonstrar como, de acordo com Honneth, o déficit sociológico se apresenta em Adorno e Horkheimer.

No artigo Teoria Critica, Honneth (1999, p. 205) procura reconstruir sistematicamente o pensamento da Escola de Frankfurt a partir da formulação de que a Adorno e Horkheimer faltava "[...] um conceito apropriado para a análise dos processos societários". Honneth contrapõe, então, o "círculo interno" - Horkheimer, Adorno e Marcuse - ao "círculo externo" - Benjamin, Neumann, Kirchheimer e Fromm.

Numa parte desse escrito, chamada "a fraqueza teórica da teoria crítica", Honneth comenta que há duas convergências entre os três membros do círculo

\footnotetext{
${ }^{5}$ Honneth, com relação a Foucault, nessa mesma entrevista, diz que, no seu caso, o déficit sociológico se dá porque ele abandona a intuição central de Durkheim, segundo a qual toda ordem de poder carece de assentimento normativo dos membros da sociedade na forma de um consenso. Esse déficit se faria presente também em Habermas, de outra maneira, pois este subestimaria em todas as ordens sociais o seu caráter determinado por conflitos e negociaçóes. Honneth conclui que essas diferentes versóes de um déficit sociológico na tradição da teoria crítica da sociedade só podem ser superadas quando se coloca no centro da vida social um conflito insolúvel por reconhecimento. Segundo suas próprias palavras (2003b, p. 23), essa proposta surge dos resultados dos estudos em Crítica do Poder e fundamenta, em boa medida, suas análises em Luta por reconhecimento.
} 
interno frankfurtiano: primeiro, a suposição de que a racionalidade humana deva ser entendida como faculdade intelectual para o domínio instrumental sobre os objetos naturais; e, segundo, que o desenvolvimento histórico consiste num processo de desdobramento desse potencial racional enquanto domínio instrumental do homem. Nessa medida, diz Honneth (1999, p. 517), “[...] permanecem ligados à tendência, já predominante em Marx, de restringir instrumentalmente a história humana para um desdobramento desenvolvimentista do procedimento societal da natureza”.

No fim dessa frase, o próprio Honneth póe uma nota de rodapé em direção à sua obra, Crítica do Poder. Trata-se do conceito esboçado nela de "modelo da dominação da natureza", que orientaria a crítica de Adorno e Horkheimer e seria responsável por fazê-los compreender a dominação social enquanto relação unilateral correlata da ação de dominação da natureza, tendente sempre ao maior controle, como veremos a seguir, em sua avaliação da Dialética do Esclarecimento.

Há, nesse momento, a contestação frontal de Honneth com relação à hipótese de fundo que sustenta a Dialética do Esclarecimento, isto é, o diagnóstico do então presente totalitário a partir da elaboração de uma filosofia da história cujo centro crítico reside na afinidade genética entre razão e dominação. Com base nesse diagnóstico, a história da humanidade se passaria unicamente como história da dominação, perdendo-se, por conseguinte, do horizonte as possibilidades de emancipação.

O que nos interessa nesse texto sobre a teoria crítica é como Honneth esclarece alguns argumentos que o norteiam na aproximaçáo entre o pensamento foucaultiano e as reflexóes frankfurtianas. Para ele, tal aproximação se dá no polo negativo, isto é, das deficiências e limitaçôes de análise que unem esses dois pensamentos. Por exemplo, como já apontamos, haveria uma espécie de "nível de pensamento funcionalista do instituto" que consistiria em desconsiderar qualquer tipo de ação social que não fosse instrumental (HONNETH, 1999, p. 532). Desse modo, entende-se que

[...] as sociedades se reproduzem, em princípio, independentemente da autocompreensão comunicativa de seus membros, na medida em que ancoram as demandas econômicas diretamente na natureza das necessidades do indivíduo com a ajuda dos processos sistêmicos de direcionamento. Como consequência desse modelo conceitual, um funcionalismo fechado pode finalmente emergir, e foi dessa forma que o 
programa horkheimeriano de um "materialismo interdisciplinar" acabou sendo apresentado. (HONNETH, 1999, p. 518).

O mesmo tipo de argumento balizará a análise honnethiana do pensamento de Foucault. O que está em jogo é uma explicação dos fenômenos sociais cuja ênfase está na relação funcional do movimento de autovalorização do capital que se daria às costas dos sujeitos. Nesse sentido, as patologias sociais (para usar uma expressão cara a Honneth) seriam explicadas exclusivamente através dos mecanismos de dominação (ou seja, pelas formas de saber e dispositivos de poder), sem recorrer às experiências dos próprios sujeitos que se inscrevem nesses processos. Faltaria a eles, Adorno e Horkheimer, e também a Foucault, portanto, uma teoria da ação capaz de explicar como os sujeitos experimentam tais patologias sociais e expressam essa vivência através de conflitos sociais e movimentos políticos ${ }^{6}$. A questão está, pois, em “[...] pensar os fundamentos normativos da crítica com base na dinâmica social efetiva ou inseridos nela, isto é, segundo as experiências de injustiça e os conflitos que se seguem a tais experiências" (WERLE; MELO, 2009, p. 184).

A filosofia da história sustentada por Adorno e Horkheimer na Dialética do Esclarecimento, por exemplo, produziria, devido a esse déficit sociológico, o entendimento funcionalista do processo histórico, quer dizer, uma leitura da história enquanto movimento superestrutural do poder infraestrutural que tende ao domínio sempre crescente. Assim, esses autores não seriam capazes de tomar em consideração a esfera comunicativa da prática social.

Não surpreende que todas as realizaçóes criativas dos sujeitos e grupos interagentes sejam vítimas desse reducionismo histórico-filosófico; toda a esfera prática diária comunicativa é tăo decisivamente excluída da investigação do processo civilizatório que os avanços sociais, do modo como ocorreram nesse período, são deixados de lado. Uma consequência

\footnotetext{
${ }^{6}$ Outro aspecto que Honneth pretende criticar é o modo como falta a Adorno e Horkheimer, por exemplo, a instância pré-teórica na qual os fundamentos da crítica se ancoram. Em $A$ dinâmica social do desprezo. Para determinar a posição de uma teoria crítica da sociedade, Honneth (2009c, p. 252) argumenta como a primeira geração da teoria crítica, devido ao impacto do fascismo e do stalinismo, vê desvanecer "[...] qualquer possibilidade de prover a perspectiva crítica da teoria de um suporte objetivo em uma instância pré-científica, seja em um movimento social ou em um interesse existente". A radicalização posterior operada por Adorno agudiza essa distância entre relação reflexiva e práxis précientífica. A radicalização da crítica da coisificação do Adorno tardio subtraiu definitivamente da teoria social qualquer esforço de denominar um momento intramundano de transcendência para prover a crítica de um suporte social; a intenção de entrar em uma relação reflexiva com a práxis pré-científica chegava a seu fim com o negativismo adorniano. (HONNETH, 2009c, p. 253).
} 
disto, como se pode ver na Dialética do iluminismo, foi a negação de uma dimensão do progresso civilizatório que não se expressa no aumento das forças de produção, mas numa ampliação das liberdades jurídicas e do escopo da ação individual. (HONNETH, 1999, p. 523).

Para Honneth, somente tendo em vista a esfera comunicativa da prática diária social é que Horkheimer e Adorno poderiam ter reconhecido que a reprodução societária "[...] nunca ocorre na forma de um cumprimento cego de imperativos funcionais, mas só por meio da integração das normas de ação específicas do grupo" (HONNETH, (1999, p. 518). Novamente, o déficit sociológico da primeira geração da Escola de Frankfurt se apresenta, sobretudo, na ênfase dos imperativos funcionais (no caso de "valorizaçáo do valor") e em suas incidências sobre o indivíduo, sem nunca pôr algum ponto de mediação entre ambas as instâncias, ignorando, dessa maneira, "[...] a existência de uma esfera intermediária da ação social” (HONNETH, 2009a, p. 102).

Conforme Nobre (2009, p. 16), Honneth entende que, desde Teoria Tradicional e Teoria Crítica de Horkheimer, vigora uma concepção de sociedade que tem dois polos e nada a mediar entre eles, "[...] posta entre estruturas econômicas determinantes e imperativas e a socialização do indivíduo, sem tomar em conta a ação social como necessário mediador. É o que Honneth denomina déficit sociológico da Teoria Crítica”.

Cumpre destacar que, para Honneth, tal déficit se encontraria igualmente em Habermas. Nesse caso, ele questiona quais são as experiências e atitudes empíricas que, em termos pré-científicos, proporcionam um indicador dos critérios normativos de Habermas, ou seja, qual é o suporte que a ideia de racionalidade comunicativa encontra nas experiências cotidianas dos atores sociais. Além disso, também salienta para o fato de que Habermas subestimaria em todas as ordens sociais o seu caráter determinado por conflitos e negociações (HONNETH, 2003). Nessa perspectiva, Honneth procura entender de que maneira o reconhecimento se inscreve nestas experiências através das expectativas morais de reconhecimento recíproco, e com isso busca propor uma alternativa a Habermas:

Com estas reflexôes chegamos ao ponto onde se perfilam os primeiros contornos de uma alternativa à versão do paradigma da comunicação relativa à teoria linguística. Seu ponto de partida está constituído pela reflexão de que os pressupostos normativos da interaçáo social não podem ser apreendidos em toda sua dimensão se se estabelecem unicamente nas condiçóes 
linguísticas de uma comunicação livre de dominação, mas sim deve ser considerado principalmente o fato de que o pressuposto do reconhecimento social está associado com o estabelecimento de comunicação em termos de expectativas normativas. (HONNETH, 2009c, p. 262).

Isso permite a Honneth introduzir uma boa dose de luta no paradigma da comunicação habermasiano, construindo uma relação entre uma racionalidade comunicativa e as experiências de desrespeito social, que levam os sujeitos a empreenderem diversas formas de luta social por reconhecimento. De acordo com Werle e Melo (2009, p. 186), o paradigma da comunicação, para Honneth, teria de ser desenvolvido não nos termos de uma teoria da linguagem, mas com base nas relaçóes de reconhecimento formadoras de identidade, isto é, da constituiçấo intersubjetiva da identidade pessoal e coletiva. Não por acaso ele afirma: "[...] quem procura integrar os avanços da teoria social representados pelos escritos históricos de Michel Foucault no quadro de uma teoria da comunicação se vê dependente do conceito de uma luta moralmente motivada” (HONNETH, 2003b, p. 23). Desse modo, a inscrição que ele faz do pensamento foucaultiano na linhagem frankfurtiana tem como produto uma leitura inovadora das heranças de Foucault e Habermas.

Podemos concluir que a noção de déficit sociológico atua como elemento regulatório dos argumentos de Honneth em direção a Adorno e Horkheimer, bem como a Foucault e Habermas. A partir de sua exposição e entendimento, podemos compreender as seguintes críticas com respeito à primeira geraçáo da Escola de Frankfurt e que lhe servem ainda para analisar o pensamento de Foucault: a questão do reducionismo funcionalista do processo histórico como desenrolar de uma dinâmica subjacente de "valorização do valor", o paradigma da dominação da natureza que compreende apenas uma modalidade da ação social orientada instrumentalmente, isto é, todas as dimensōes da ação social seriam concebidas como prolongamentos da dominação humana da natureza; e a dificuldade em considerar as realizaçóes progressistas devido a uma crítica radical da razão. São estes os elementos que norteiam não só o artigo sobre a teoria crítica, como também a obra Crítica do Poder. São, ainda, os eixos que balizam a aproximação entre Foucault e a primeira geração da Escola de Frankfurt operada por Honneth.

Em todos esses casos, existe a falta de instâncias intermediárias. O processo histórico é visto como, por um lado, desenvolvimento de uma lógica subjacente de poder e, por outro, como materialização de seus efeitos 
através das instituiçốes sociais, sem qualquer ponto de mediação capaz de interromper essa dinâmica. $\mathrm{O}$ paradigma da dominaçáo da natureza pressupóe tanto processos de racionalização e controle da vida, quanto indivíduos passivos, quase meros produtos ou resultados. Por fim, a crítica radical da razão denunciaria seu conluio com as formas de dominação, ao mesmo tempo em que não se ancoraria em nenhuma outra forma possível de racionalidade que lhe possibilitasse fundamentar essa própria crítica.

\section{A Crítica À primeira geraçáo da Escola de Frankfurt e a emergênCia da CRítica A Michel Foucault}

O objetivo da obra Crítica do Poder é reconstruir histórica e sistematicamente as fases da Teoria Crítica, tendo como etapas, grosso modo, os anos trinta com a distinçáo horkheimeriana entre teoria tradicional e a teoria crítica, os anos quarenta e cinquenta, com o estágio de negativismo filosófico-social adorniano, chegando por fim às formulaçôes de Habermas e Foucault, na década de 1960:

Ao longo desse estudo meu objetivo não foi outro senão o de lançar luz sobre os problemas fundamentais que, a partir do ponto de vista histórico, aparecem relacionados com o nascimento de uma Teoria Crítica da Sociedade. Daí que, num primeiro nível, no que diz respeito ao desenvolvimento histórico da teoria, fui guiado pela convicção de que as duas aproximaçóes mais inovadoras e influentes da Teoria Crítica, a saber, as empreendidas por Michel Foucault e Jürgen Habermas, podem ser entendidas como dois desenvolvimentos rivais dentro de um âmbito de questóes que já havia sido previamente aberto pela Teoria Crítica. (HONNETH, 2009a, p. 21)

Em linhas gerais, na primeira parte, intitulada $A$ incapacidade para a análise social: as aporias da teoria crítica, Honneth procura partir da reflexão na qual Horkheimer distingue a teoria tradicional da teoria crítica, a fim de mostrar o que ele entende por déficit sociológico. A obra continua a análise da Dialética do Esclarecimento, mostrando como a teoria crítica se constrói como filosofia da história sustentada no modelo de dominação da natureza e finalmente aborda a teoria da sociedade de Adorno como chegada a um beco sem saída, com a formulação de uma repressão definitiva do social. 
O que marca a transição da década de 30 - isto é, da proposta de Horkheimer de distinguir entre a teoria crítica e a tradicional, no sentido de estabelecer um campo de conhecimento capaz de desenvolver uma crítica da sociedade efetivamente existente - para a década de 40 é uma mudança em direção à filosofia da história. É nesse sentido que se inicia o capítulo 2: $O$ giro até a filosofia da história na Dialética do Esclarecimento: uma crítica da dominação da natureza. Em termos históricos, Honneth (2009a, p. 74) assinala que o ponto nevrálgico da teoria crítica não é mais, como na crítica horkheimeriana dos anos 30 , a desilusão das esperanças revolucionárias, mas sim o horror produzido pelo progresso histó

A brusca transformação da Revolução Soviética em burocracia estatal ditatorial de Stálin, a consolidação terrorista dos aparatos fascistas de poder na Europa e o crescimento aparentemente sem limites do capitalismo norte-americano são para ele formas de desenvolvimento apenas um plano superficial diferentes de um único processo histórico cuja culminação não é senáo um sistema de dominação total. (HONNETH, 2009a, p. 74).

Diante dessa conjuntura histórica, o núcleo duro dessa nova concepção da Teoria Crítica gira em torno de uma filosofia da história capaz de elucidar a condição de possibilidade dessa dominação. Em outras palavras: a "[...] gênese histórica da dominação total” (HONNETH, 2009a, p. 76). A função da crítica, na década de 40, é clarificar a origem e a dinâmica desse processo de precipitação na barbárie que persiste no seio do projeto de modernização enquanto progresso.

A dominaçáo da natureza constituiria, dessa maneira, o núcleo com base no qual se decifra, com a ajuda de uma filosofia da história, o fenômeno civilizatório, compreendido como processo de crescente reificação da sociedade. Na opinião de Honneth (2009a, p. 99), o processo de dominação social aparece, então, para Adorno e Horkheimer, como o correspondente do reflexo estrutural do processo de controle instrumental. Emerge nesse momento a ideia, já mencionada por nós, de um nivel funcionalista da investigação da primeira geração da Escola de Frankfurt, o qual faria desconsiderar qualquer possibilidade de autonomia relativa das instituiçóes sociais, face ao processo de produção capitalista, uma vez que, vistas como meros reflexos, não passam de efeitos de superfície.

A correspondência existente entre a dominaçáo da natureza e a dominação social não lhes permite tomar em consideração outro modelo de dominação social mediante coação direta ou indireta; mas aqui, por princípio, impede-se qualquer tipo de reconhecimento geral das próprias 
atividades culturais e as funçóes hermenêuticas dos grupos submetidos ao sistema social. (HONNETH, 2009a, p. 102).

Adorno e Horkheimer não contemplariam, assim, a possibilidade de uma esfera independente e intermediária de ação cultural, na qual os membros de um grupo social determinado tenham suas expectativas cotidianas e seus interesses recíprocos como objeto de acordo dentro de uma visão comum, em um espaço público regulado democraticamente. Esse tipo de crítica se fará presente de igual modo na análise da obra de Foucault, pois este também negligenciaria tal fator.

Logo, a dimensão funcionalista do pensamento de Adorno e Horkheimer, sustentada no nível de análise pelo modelo de dominação da natureza, desemboca numa insuficiência crítica diante das outras possibilidades de ação social para além da modalidade instrumental. Honneth direciona sua crítica ao fato de que tanto Adorno quanto Horkheimer tornam impossível um tipo de dominaçáo assegurado consensualmente. A conclusão de Honneth é a de que

[...] nestas duas versões sucessivas da Teoria Crítica, o marco conceitual da teoria da ação se vê reduzida ao conceito de trabalho; em ambas versóes, por consequência, a história das sociedades humanas apenas é concebida em conexão com a dinâmica da dominação humana da natureza. [...] Dialética do Esclarecimento, menos de uma década depois, atribui o impulso original da decadência da civilização a um processo de dominaçáo tecnologicamente progressivo da natureza. (HONNETH, 2009a, p. 103).

A última fase desse primeiro momento da Teoria Crítica é, para Honneth (2009a, p. 105), "[a] teoria da sociedade de Adorno: a repressáo definitiva do social". Se tocamos, até agora, em dois pontos fundamentais da crítica de Honneth à primeira geração - isto é, o paradigma da dominação e o nível funcionalista de análise - é na avaliação do pensamento adorniano pósDialética do Esclarecimento que as aporias da crítica à razão aparecem como elementos a serem necessariamente superados por outro tipo de crítica, a qual leve em conta outra face da razão que não seja instrumental ${ }^{7}$.

\footnotetext{
7 Esse tipo de crítica seria aquela que recorre a outra modalidade de razão que não a instrumental. De acordo com Rouanet (1987), o conceito de racionalidade de dupla face, isto é, instrumental e comunicativa, é criado por Habermas com o objetivo de superar as seguintes aporias da crítica de Adorno: primeira, aquela de uma razão que continua exercendo sua atividade, mesmo depois de ter perdido todo direito à existência devido ao seu entrelaçamento com a dominação; segunda, aquela que,
} 
Para Honneth, embora Adorno e Horkheimer, na Dialética do Esclarecimento, descubram no primeiro momento do processo de regressão da espécie o marco da realidade histórica da Alemanha, ou seja, promovam um diagnóstico do presente ancorado no paradigma da dominação da natureza, perscrutando no início da civilização o processo de racionalidade que promove dominação, eles não apreciariam que esse fenômeno possa ter chegado ao seu fim, justamente na derrocada do regime fascista. Honneth recorre, pois, à seguinte passagem:

Na Alemanha, o fascismo venceu sob uma ideologia crassamente xenófoba, anticultural e coletivista. Agora que ele está devastando a terra, os povos têm que lutar contra ele, não há saída. Mas quando tudo houver acabado, não é preciso que o espírito da liberdade se difunda sobre a Europa, suas naçóes podem se tornar tấo xenófobas, hostis à cultura e pseudocoletivistas como era o fascismo do qual tiveram de se defender. Mesmo a sua derrota não interrompe necessariamente o movimento da avalancha. (ADORNO; HORKHEIMER, 1985, p. 182).

Quer dizer, para Adorno e Horkheimer, após o fascismo, não viria um período de Luzes, um Esclarecimento reabilitado. Pelo contrário, o fascismo teria aberto o sulco pelo qual passaria incessantemente o totalitarismo, mesmo que com outras fachadas. Os atuais acontecimentos do início do século XXI envolvendo os imigrantes europeus ou mesmo a guerra contra o terror parecem confirmar esse raciocínio (AGAMBEN, 2007). Contudo, Honneth vê nesse movimento reflexivo uma aplicação fora de contexto. A interpretação genealógica do totalitarismo fascista passa a ter como missão diagnosticar criticamente a situação das democracias de Estado de Bem-Estar Social existentes no capitalismo tardio:

na esteira de Nietzsche, realiza uma crítica total da razão que compromete seus próprios fundamentos, pois utiliza as armas da razão para denunciar a razão; e terceira, a que se refere à necessidade de ultrapassar o conceito através do próprio conceito, isto é, afirmar a năo-identidade por meio de um procedimento cuja lei de funcionamento é justamente subsumir o não-idêntico na unidade do idêntico. Isso permitiria a Habermas salvar o fundamento que possibilita o exercício crítico, já que é uma forma de racionalidade, a comunicativa, que permite realizar a crítica. Em Honneth, essa aporia se apresenta mais preponderantemente no primeiro sentido salientado por Habermas, ou seja, como a perda do fundamento social da própria crítica exercida por Adorno, na medida em que este não encontra suporte empírico para as suas reflexôes. Enquanto Habermas (2001) defende que isto é um produto da leitura negativa da modernidade a partir de Weber e Lukács, Honneth, por sua vez, compreende como um déficit ou mesmo como um "girar em falso" da crítica adorniana, em face de um mundo que não é necessariamente totalitário. 
Com a visada posta em uma interpretação filosófico-histórica do fascismo, a Teoria Crítica que Adorno desenvolve em seus escritos durante a fase pós-guerra dirige sua atenção à Alemanha capitalista na situação de reconstrução. Sua teoria encontra em uma situação paradoxal: por um lado, está equipada com as ferramentas conceituais adequadas para uma análise da dominação totalitária, estas, como é natural, por outro lado, já não são úteis para a investigação da forma normal de dominação capitalista. (HONNETH, 2009a, p. 106).

Dessa situação paradoxal da crítica, Honneth faz devir uma situação aporética insustentável para uma análise das sociedades contemporâneas: a Teoria Crítica gira em falso no novo tempo histórico pós-fascismo. Exemplo dessa situação aporética está na definição de razão instrumental, a qual se torna tấo amplificada em Adorno e Horkheimer que inclui também o próprio pensamento filosófico, aquilo que em si mesmo poderia servir como possibilidade emancipatória. A questão de como o pensamento pode escapar à sua junção com a racionalidade instrumental se torna elemento de preocupação central em Adorno, através de seu próprio exercício filosófico.

Na Dialética Negativa, por exemplo, o tom se agudiza diante do novo tempo histórico: "A filosofia, que um dia pareceu ultrapassada, mantém-se viva porque se perdeu o instante de sua realização" (ADORNO, 2009, p. 11). O que passa a estar em jogo, no procedimento filosófico adorniano pósDialética do Esclarecimento, é a situação paradoxal de um pensamento que insiste em sustentar a irredutibilidade do não-idêntico, mesmo concebendo que "[...] pensar significa identificar" (ADORNO, 2009, p. 12-13). Tratase, para Adorno, de manter a radicalidade da crítica do presente à revelia do argumento segundo o qual "o pior já passou”. Como destaca Nobre (2009), é um pensar que pensa contra o pensamento, que se vira contra as nossas próprias estruturas de pensamento, denunciando o conluio da forma de nossa racionalidade com a forma de dominação vigente.

Honneth (2009a, p. 113), por sua vez, não hesita em demonstrar claramente os problemas desse procedimento filosófico. Ele pergunta: como é possível uma Teoria Crítica sob as premissas de uma construção históricofilosófica que sempre descobre de imediato em cada ação de conhecimento conceitual o signo de uma poderosa dominação da natureza, sob cujo domínio a própria humanidade se encontra alienada? Como, em virtude dessas premissas, ela é capaz de realizar afirmaçóes legítimas sobre a realidade, se em 
princípio apenas é capaz de descobrir e abrir-se à realidade com a ajuda do conhecimento conceitual?

Descortina-se aqui outro ponto importante da crítica de Honneth, e que o aproxima de Habermas, a saber, a situação paradoxal e aporética do exercício da crítica radical à Razão. Para Honneth, o paradigma da dominação da natureza analisa apenas uma modalidade de ação social e é incapaz de valorizar as realizaçóes progressistas ${ }^{8}$ devido a uma crítica radical da razão. Aliás, neste ponto, podemos antecipar como ele entende as similitudes entre Foucault e Adorno nesse sentido:

Todos os dados sociais e culturais da sociedade burguesa, instituiçóes, culturas e formas de consciência que ela criou, tornam-se, desta maneira, encarnações de uma força motriz originária, seja a partir da vontade de poder ou da tendência à dominaçáo subjetiva do mundo. Como Adorno e Foucault compartilham este problemática redução com as teorias da época pós-moderna e dificilmente podem corresponder ao conteúdo racional do processo de racionalizaçáo moderna, enredam-se na mesma aporia de uma crítica totalizadora da razáo: não podem nem devem estar seguros de seu próprio meio, do conteúdo racional dos argumentos teóricos. (HONNETH, 2009d, p. 140).

Nobre (2009, p. 50) assim comenta essa aporia oriunda do próprio exercício crítico: se a razão instrumental é a única forma de racionalidade, bloqueando qualquer possibilidade de emancipação, em nome do que é possível criticar a racionalidade instrumental? Para Nobre, e também para nós, Adorno e Horkheimer assumem conscientemente essa aporia ${ }^{9}$, defendendo que ela é a condição de emergência de uma crítica cuja possibilidade se tornou extremamente precária. Por conseguinte, em vez de o pensamento buscar a soluçáo dessa aporia, ele se sustenta nela para produzir efeitos de análise

\footnotetext{
${ }^{8}$ A discussão em torno de como Honneth compreende a noção de progresso é pertinente e complexa. Poderíamos indicar, a esse respeito, o último capítulo de Luta por reconhecimento, intitulado Perspectivas de filosofia social: moral e evoluçáo da sociedade. No que se refere ao escopo do presente trabalho, apontamos tão somente para o fato de que seu argumento também se sustenta na afirmação, igualmente defendida por Habermas, de que Adorno, Horkheimer e Foucault desconsiderariam, em suas análises, outra dimensão da história que não fosse a do crescente incremento dos processos de racionalização.

${ }^{9}$ Habermas (2002, p. 170), nesse sentido, salienta que Adorno era consciente daquilo que ele chama de contradiçấo performativa: "Esta descreve, contudo, a autodestruiçẫo da capacidade crítica de modo paradoxal, visto que no instante da descrição ainda tem de fazer uso da crítica que declarou estar morta. Ela denuncia o esclarecimento que se tornou totalitário com os meios do próprio esclarecimento. Adorno estava perfeitamente consciente dessa contradição performativa da crítica totalizada”.
} 
sobre o presente. Voltaremos a esse ponto, na medida em que o consideramos elemento central numa possível resposta às críticas de Habermas e Honneth, bem como de atualização da crítica radical na contemporaneidade.

Assim como o modelo de dominação da natureza de Adorno e Horkheimer seria capaz apenas de diagnosticar uma forma de dominação unívoca e crescente, Foucault compartilharia, segundo Honneth, a noção de que o processo civilizatório pautado na racionalidade instrumental culmina em organizações de dominação capazes de controlar e dirigir os indivíduos e a vida social. Nessa perspectiva, Maia (2002, p. 72) enfatiza que Honneth aponta como elementos comuns às análises de Foucault e Adorno a compreensão de que a racionalização social implicaria violência ao corpo humano e o entendimento de que o processo civilizatório se daria precipuamente por meio do progresso exclusivo da racionalidade técnica ou instrumental.

Ambos, Adorno e Foucault, veriam o fundamento de sua crítica danificado, uma vez que o próprio processo de construção racional da crítica se encontraria emaranhado com o seu objeto, as relaçóes de poder e a dominaçáo. Podemos ilustrar melhor essa questão através das palavras de Habermas (2002, p. 261), para quem a aporia surge como "contradição performativa":

A autocrítica totalizante da razão enreda-se na contradição performativa: não pode convencer a razáo centrada no sujeito de sua natureza autoritária senão recorrendo aos próprios meios dessa razão.

Não apenas o termo é o mesmo usado por Habermas e Honneth, "totalização da crítica", mas também seus resultados: uma aporia que tornaria insustentável o próprio exercício crítico. De acordo com a visão comum a Habermas e Honneth, tornando-se total e tendo por alvo a própria razão, a crítica anularia sua pretensão de validade. A totalização da crítica exercitada por Adorno e Horkheimer, portanto, conduziria a filosofia inevitavelmente a uma direção aporética, ao beco sem saída do ceticismo, como assinala criticamente Cachopo (2008).

Quando se defronta com o pensamento foucaultiano, em Crítica do Poder, Honneth se serve de boa parte dos argumentos empregados na análise acerca da primeira geração da teoria crítica, de sorte que o entendimento de seu ponto de partida, a noção de déficit sociológico, além das questôes do nível funcionalista de análise, o paradigma da dominação da natureza que produz o entendimento exclusivo de uma modalidade de ação social e a desconsideraçáo 
de determinados progressos da modernidade, são fundamentais para compreender a sua leitura de Foucault.

A partir desta exposição dos elementos centrais da crítica que Honneth faz à primeira geração da Escola de Frankfurt, podemos iniciar nossa análise quanto ao foco de nosso trabalho, a saber, do modo como Honneth entende a pertença de Foucault à teoria crítica. Assim, exporemos e discutiremos as questôes centrais que balizarão seu encontro com Foucault: o funcionalismo orientado historicamente, a correlação entre poder e coerção, provocando uma leitura behaviorista da integração social, e a desvalorização da ordem jurídica. Três problemáticas que emergem da mesma perspectiva usada com relação à primeira geração da Escola de Frankfurt.

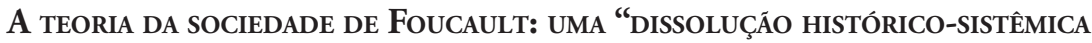 da Dialética do Esclarecimento"}

Enquanto a primeira parte de Crítica do Poder é dedicada à avaliaçáo do pensamento da primeira geração da Escola de Frankfurt, em especial Adorno e Horkheimer, como vimos, na segunda, $O$ redescobrimento do social. Foucault e Habermas, Honneth (2009a, p. 165) expóe o estatuto do pensamento de Foucault face à tradição crítica, entendendo as teorias desenvolvidas por Foucault e Habermas como escolas de pensamento que competem por serem a continuação da Teoria Crítica trabalhada por Adorno, e nas quais duas questóes tomam desenvolvimentos opostos: de um lado, os modos de dominação e, de outro, as formas de integração nas sociedades do capitalismo tardio. Enquanto "[...] a teoria da sociedade de Foucault representa, em última instancia, uma forma de dissolução teórico-sistêmica dos conteúdos desenvolvidos na Dialética do Esclarecimento", Honneth compreende, por outro lado, "[...] a teoria da sociedade de Habermas em termos gerais como uma 'transformação teóricocomunicativa' da Dialética do Esclarecimento” (HONNETH, 2009a, p. 166).

A investigação de Honneth se concentra na passagem da arqueologia do saber à genealogia do poder, situando como momento de transição expressóes nas quais Foucault sinaliza estar se referindo não mais ao grande modelo da língua e dos signos, mas sim ao da guerra e da batalha, focalizando, dessa maneira, as relaçôes de poder e não de sentido (FOUCAULT, 2004, p. 5).

Pode-se sublinhar aqui a centralidade da noção de poder no pensamento foucaultiano dos anos setenta, permitindo que o pensador francês se distancie 
sobretudo do marxismo clássico carente de um programa capaz de compreender os mecanismos de integração social das sociedades desenvolvidas, pois teria permanecido preso a concepçôes "pré-modernas" de poder. Isso porque, no marxismo e também na teoria clássica, o ponto de partida é o sujeito em posse do poder, utilizando meios para impor proibiçôes e instruçóes que lhe possibilitam realizar seus objetivos de domínio, centralizados no aparato estatal. Em oposição, Foucault proporia um modelo estratégico de poder cuja característica precípua provém da tentativa de traduzir a teoria de poder nietzschiana para o quadro de uma teoria da sociedade.

Para Honneth, Foucault, tanto quanto Adorno, compreende as estruturas sociais em geral como formas coaguladas de uma atividade de controle dirigida tanto à natureza externa como à interna. Com a diferença de que Foucault parte de uma dimensão ainda mais específica da ação social, o modelo da intersubjetividade estratégica da luta (HONNETH, 2009a, p. 241). Em outras palavras, tratar-se-ia da luta como modelo básico da ação social. Honneth ressalta que esse pressuposto da batalha perpétua contém em si um problema, qual seja: de que maneira a unidade de uma estrutura de poder, por mais momentânea que seja, pode ser deduzida da situação social de luta ininterrupta?

A teoria foucaultiana da ação social partiria da premissa de que o contexto da vida social pode ser observado como processo de conflitos estratégicos entre atores, e que o poder social, em nível fundamental, pode ser interpretado simplesmente como êxito em uma situação de luta. Assim, ela conteria, de forma implícita, uma crítica da tradição da teoria social centrada no reconhecimento normativo do poder social.

Segundo Honneth, existe certa dificuldade foucaultiana em compreender a possibilidade de estabilização de posiçôes de poder estrategicamente conquistadas. No mundo social constituído exclusivamente por situaçóes de ação estratégica, não poderia se desenvolver em nenhum caso algo como um consenso normativamente motivado, já que os sujeitos deveriam necessariamente se perceber como oponentes interessados no êxito com respeito aos fins. Disso resultaria o rechaço foucaultiano das normas jurídicas e das orientaçóes morais que regulam a interação dos membros da sociedade, percebidas por ele como meras ilusôes ou enganos culturais:

Neste esquema de pensamento, que acabamos de perfilar a grandes traços, se deduz para Foucault sobretudo a necessidade de rechaçar as normas jurídicas e as orientaçóes morais que regulam a interação dos membros da sociedade entre si, entendidas agora como meras ilusóes ou enganos 
culturais. No perpétuo combate das lutas sociais, no qual uma ordem social de dominação alcança em certo sentido sua existência, as normas jurídicas e as atitudes morais tâo só possuem a função de esconder os objetivos estratégicos e velar a situaçấo cotidiana de conflito. Frente à inalterável substância da luta, elas representam, por assim dizer, meras superestruturas historicamente modificáveis. (HONNETH, 2009a, p. 248, grifos nossos).

Quer dizer, tendo em vista o perpétuo combate das lutas sociais, no qual uma ordem social de dominaçáo se efetiva, as normas jurídicas e atitudes morais teriam tão somente a função de esconder os objetivos estratégicos e velar a situação cotidiana de conflito. Honneth se refere à ideia de que existiria uma infraestrutura dinamizada pelo processo de intensificação de poder, na direção de sua otimização e maximização, onde as normas jurídicas e valores morais aparecem como meros fenômenos ou atendendo à função de incremento de poder. Essa é uma das críticas de Honneth em relação a Foucault. Tratar-seia da extensão do funcionalismo presente na primeira geração da Escola de Frankfurt.

O que para Honneth, em contrapartida, resulta importante nessa exclusão teórica de toda dimensão possível efetiva de acordo normativo se resume na seguinte questão: sem a possibilidade do consenso normativo, como uma estrutura de poder qualquer pode estar em mínima estabilidade, se ela deriva de uma luta ininterrupta, ou seja, sem que seja atendido o requisito da interrupção dos processos em conflito?

A maneira como Foucault analisa as formas de integração social característica das sociedades modernas seria construída, para Honneth, conforme o modelo das instituiçôes totais. Tomar o nascimento da prisão como objeto de investigação se explicaria, nesse raciocínio, por ser esta um lugar onde se pode compreender a dinâmica da própria sociedade, que se dissemina para outras instituiçôes, como a escola, o hospital, o quartel etc.

Em Vigiar e Punir, duas imagens marcam a formação do sistema moderno de poder: o relato de uma execução cruel ocorrida em 1757, em Paris, e a descriçáo do projeto de 1836 para uma cidade penal projetada como sistema de supervisão total.

A passagem da execução sumária, do espetáculo de retalhamento corporal, para a pena de reclusão, em Foucault, não significaria humanização, mas sim otimização do processo de controle social. A diferença entre ambas 
concerne à economia do poder. Em outras palavras, na execução espetacular está em jogo a restauração da soberania colocada em xeque; já a prisão é o exemplo institucional que dá materialidade explicativa à teoria foucaultiana do poder, evidencia-o através de técnicas de dominação social que se orientam e, portanto, podem ser mais bem compreendidas, principalmente pelos seus efeitos sobre a conduta corporal dos indivíduos.

Honneth argumenta que, se em As Palavras e as Coisas era o pensamento clássico que estava em jogo, no Vigiar e Punir é o sistema clássico da lei penal, especificamente a reforma da lei penal, a qual tem raízes filosóficas nas teorias burguesas do contrato social e termina por converter o "homem" em limite da legitimidade da autoridade punitiva. Tal reforma consiste na crítica direta às técnicas de tortura, através da defesa do argumento de que as penas devem instruir e na defesa também da humanizaçáo dos instrumentos empregados na punição aos infratores da lei.

O desenvolvimento argumentativo de Foucault estaria próximo a um funcionalismo orientado historicamente (HONNETH 2009a, p. 275), por compreender as ideias e os valores constituídos historicamente apenas do ponto de vista exclusivo da função objetiva que desempenham dentro de um processo sistêmico dirigido à obtenção de mais poder. No entanto, quais os critérios para se dizer que tais instrumentos são mais efetivos do que os anteriores? A sugestão de Honneth é que são possíveis duas respostas: na primeira, o exercício de controle social mudaria com a transformação das formas de dominação social e seu nível de efetividade dependeria das condiçóes particulares pelas quais se constitui a forma específica de dominação social; na segunda, os pontos de referência que definem o exercício de controle social são historicamente variáveis e determinados por um optimum de controle descrito objetivamente, que torna possível medir a efetividade das formas individuais de controle social, independentemente do marco institucional no qual elas se situam.

Das diferenças existentes entre essas duas possibilidades próprias de uma análise funcionalista derivariam, ainda de acordo com Honneth, distinçôes que não seriam de pouca relevância para o modo de proceder de Foucault. No encaminhamento da primeira resposta, o eixo se localiza na ordem social e econômica a partir do qual se examinam e se póem à prova os meios de controle que são adequados, como é o exemplo de Rusche e Kirchheimer, membros da primeira geração da Escola de Frankfurt que produziram um trabalho, citado por Foucault em Vigiar e Punir, sobre a relação entre sistema penal e capitalismo. No interior da análise foucaultiana, a transformação dos 
indivíduos em corpos dóceis e úteis estaria em conformidade com o sistema capitalista de produção. Quanto à segunda resposta, haveria o processo de incremento e intensificação do poder social cumprindo sua função dentro de um quadro de referências invariável:

Se Foucault segue com um procedimento metodológico deste tipo, tem que intentar observar todos os processos sociais a partir de uma perspectiva funcionalista não só atendendo à conservação, mas também à questão do incremento do poder, e isto significa a partir do ponto de vista da finalidade objetiva de lograr o máximo de controle de todos os processos da vida social. (HONNETH, 2009a, p. 278).

$\mathrm{Na}$ questão dos procedimentos de controle corporal analisados em Vigiar e Punir, Foucault realizaria uma pré-história, descrevendo métodos, técnicas e conhecimentos que se formaram desde o século XVI, a partir de diversas instâncias disciplinares, com o fim de normalizar e adestrar a conduta dos corpos humanos. Além disso, comenta Honneth (2009a, p. 284), Foucault deduziria a tese segundo a qual nos centros disciplinares a vida psíquica interior dos sujeitos só é capaz de surgir sob a coação de um disciplinamento corporal gradualmente intensivo. É o que se pode chamar uma genealogia da alma moderna, fundamentada na história dos métodos de controle.

A crítica de Honneth é que, ao tomar as influências sociais como meros procedimentos coercivos externos que produzem sujeitos e formam um tipo de vida psíquica, Foucault se orientaria por uma forma de behaviorismo que representaria os processos psíquicos apenas como resultados de condicionamentos constantes, estabelecidos a partir do exterior e imunes à intervenção ativa destes sujeitos. Desse modo, "[...] o sujeito moderno no fim das contas não é outra coisa senão a unidade fictícia gerada por regras de discurso anônimas ou produzidas por estratégias" (HONNETH, 2009d, p. 147).

Honneth retoma, ainda, o tema do funcionalismo para afirmar que Foucault impulsiona sua investigação por esse modelo, por conceber a sociedade como um complexo de estratégias respectivas de poder sob o qual os problemas são considerados em termos invariantes, ou seja, concebe o social a partir exclusivamente do processo de incremento do poder:

De outro ponto de vista finalmente, há outros aspectos na argumentação foucaultiana, em verdade, bastante próximos a uma versão grosseira do behaviorismo, que também se ajusta a uma concepção em princípio mecanicista. A partir da perspectiva da teoria de sistemas, contempla os 
processos sociais enquanto processos sistêmicos de incremento de poder. (HONNETH, 2009a, p. 293).

O modelo teórico-sistêmico seria subjacente à investigação histórica de Foucault, pelo fato de que a evolução social seria concebida exclusivamente como processo de incremento do poder social, desenvolvendo-se conforme a lógica de periódicas adaptaçóes, entendendo-se os conflitos sociais como terreno cotidiano sobre o qual o processo sistêmico abre caminho.

Se Foucault, em contraste com isso, argumenta Honneth, tivesse seguido de maneira mais consequente a esteira de seu modelo original de ação, valorizando as formas existentes de dominação social como produtos de conflitos sociais e não como resultados de um processo sistêmico de adaptação, não teria podido evitar dotar conceitualmente os atores sociais de motivaçóes que em geral desencadeiam a revolução política e o conflito social. Na verdade, através dessa crítica, descortina-se a proposta honnethiana de uma luta por reconhecimento, de um embate motivado moralmente.

Em Foucault, não existiria distinção entre organizaçôes sociais cujos membros se regulam sobre a base de contratos juridicamente livres e instituiçôes totais, cujos membros são coagidos. Seria possível a Foucault passar por alto dessas diferenças, porque definiria a lei e a moralidade como simples instrumentos de encobrimento cultural de fins estratégicos.

Assim, o recurso ao panoptismo encerraria, em si mesmo, a ideia da regulação de condutas vinculada a um sistema fechado e autorregulado, exemplificando ainda uma outra visão de sociedade unidimensional (MARCUSE, 1979) ou de sociedade administrada (ADORNO; HORKHEIMER, 1985), na qual os sujeitos seriam coagidos a adaptar-se não através da manipulação de seus impulsos psíquicos, mas sim através do disciplinamento de sua conduta corporal.

Fazendo menção a uma frase do Vigiar e Punir, “[...] as Luzes que descobriram as liberdades também inventaram as disciplinas" (FOUCAULT, 2009a, p. 209), Honneth defende que se trata de uma correspondência direta com a Dialética do Esclarecimento. Foucault, aparentemente como Adorno, identificaria o curso da história europeia ao processo de racionalização no qual os meios de dominação são aperfeiçoados gradualmente sob o véu da emancipação moral. O que Foucault chama de "lado escuro" do processo civilizador moderno é concebido por Adorno e Horkheimer como "história subterrânea da Europa”. Como Adorno, Foucault veria igualmente o processo 
de racionalização técnica determinando subterraneamente o curso da história europeia.

Ambos entenderiam que nem os grupos sociais nem as convicções normativas nem as orientações culturais dos sujeitos socializados têm função importante na integração social das sociedades do capitalismo tardio, tratando-se unicamente de uma organização sistêmica independente: Adorno consideraria que a administraçáo centralizada leva a cabo o processo de dominação; Foucault, por sua vez, veria a sujeição assegurada pelos procedimentos de controles disciplinares, produzidos em organizaçóes institucionalmente adjacentes, tais quais a escola, a prisão e a fábrica. Desse modo, argumenta Honneth (2009d, p. 140), Adorno e Foucault convergem no diagnóstico da forma de integraçáo das sociedades contemporâneas, pois compreendem que "[...] o processo de civilização da racionalização instrumental culmina em organizaçôes de dominação que são capazes de controlar e conduzir por completo a vida social”. Nesse sentido, a estabilidade das sociedades seria unicamente o resultado do trabalho controlador de organizações administrativas que intervêm como instituições totais nas vidas de cada indivíduo para fazer dele disciplinado e controlado, manipulado e adestrado, integrante dócil da sociedade.

Por conseguinte, da mesma maneira como Honneth compreende que Adorno e Horkheimer concebiam apenas uma modalidade da ação social, a instrumental, igualmente Foucault, segundo ele, proporia, como aquilo que torna possível a subjetividade, uma espécie de descrição behaviorista da relação entre poder e coerção:

Se Foucault realmente supóe que a origem da subjetividade humana se forja e ajusta deste modo, deveria ter sido guiado por uma versão de behaviorismo: representa os processos psíquicos como o resultado de um condicionamento constante. [...] Por causa de sua bagagem inicial estruturalista, Foucault, uma vez que dá a sua teoria do poder a forma de uma investigação histórica, descreve os sujeitos de modo behaviorista, como criaturas informes, totalmente suscetíveis de serem condicionadas. (HONNETH, 2009a, p. 286 e 299).

No entendimento de Honneth, ambos os autores (e também Horkheimer) situariam na base de suas teorias um modelo coercitivo de ordem social. Foucault descrevendo os sujeitos de modo behaviorista, como criaturas informes, totalmente suscetíveis de serem condicionadas e Adorno, 
por sua vez, analisando a dominação dos indivíduos a partir do produto histórico de um processo de civilização que retroage às fases mais iniciais da história humana. Se ambos convergem acerca do diagnóstico, isto é, a respeito do processo de racionalização técnica dos instrumentos da dominação social, divergem pelo fato de que Adorno tenta extrair consequências intrapsíquicas e sociais, com base em três dimensôes que se implicam mutuamente: produção social, dominação social e formaçáo da personalidade. Para Foucault - e aqui está uma divergência entre ambos -, as questóes seriam dirigidas à segunda dessas três dimensóes, entendendo a história das sociedades apenas como processo sistêmico que tende ao incremento da capacidade do poder.

Honneth denomina modelo de dominação da natureza o que sustenta as reflexôes adornianas, e de racionalidade estratégica a base das formulaçóes foucaultianas. $\mathrm{Ou}$, ainda, chama esta de "versão teórico-sistêmica" de cunho funcionalista, pois se trata de incremento do poder social se ramificando ao longo da textura das relaçôes humanas.

A conclusão de Honneth (2009a, p. 301) é a de que, em verdade, nem a Teoria Crítica de Adorno nem sua continuação sistêmica, a teoria do poder de Foucault, nos proporcionam o instrumental adequado para analisar as formas de integração das sociedades tardo-capitalistas. Trata-se, como se pode verificar, de uma aproximação dos pensamentos de Foucault, Adorno e Horkheimer pela via das limitaçóes de análise. Em contraste, na parte final de Crítica do Poder, Honneth enfatiza que a teoria social de Habermas oferece uma oportunidade efetiva de compreensão destas sociedades, porque abre espaço para a compreensão da possibilidade da comunicação e consenso no tecido social.

\section{RelevânCia do trabalHo de HonNeth E INTERrogaÇóes da VinculaÇÃo entre Foucault e a Teoria Crítica}

Em que pese ter sido o primeiro grande trabalho a perfilar Habermas e Foucault como desenvolvimentos da teoria crítica da primeira geração, o impacto de Crítica do Poder não foi devidamente dimensionado. No Brasil, fora o trabalho de Maia (1999), não se ouviu quase nenhum ruído de tal proposta. Ademais, sua intenção era: por um lado, mapear uma convergência entre o diagnóstico articulado por Habermas na Teoria do Agir Comunicativo, no que tange à colonização do mundo da vida, e as consequências depreendidas das análises foucaultianas do poder, sobretudo nas discussóes concernentes às lutas transversais; por outro lado, apontar as convergências entre a crítica 
foucaultiana da modernidade, elaborada no período genealógico, especialmente na obra Vigiar e Punir, e a crítica formulada por Adorno e Horkheimer, na Dialética do Esclarecimento.

Nessa perspectiva, o fato de Honneth desconsiderar, em sua tentativa de vincular Foucault à Escola de Frankfurt, outra modificação ocorrida no interior do pensamento foucaultiano, aquela empreendida a partir de 1978 em direção à estética da existência e à ontologia histórica de nós mesmos, continua sem um estudo mais detalhado. Malgrado esse fato, o trabalho de Maia constitui uma empresa fundamenta ${ }^{10}$ para a articulação de duas grandes tradiçóes do pensamento contemporâneo que podem fornecer excelentes ferramentas conceituais para a análise de nosso tempo histórico.

Jay (1996) analisa de modo positivo as aproximaçóes esboçadas tanto por pensadores como Foucault, Derrida e Lyotard, como estudos posteriores que intentam entrelaçar a teoria crítica com o chamado pós-modernismo. Através desse encontro entre o pensamento francês e a teoria crítica alemã se evidencia a demonstração da vitalidade da Escola de Frankfurt no final do século XX.

Podemos assim examinar a proposta de Honneth: se, por um lado, tem seu feito original de pôr Foucault praticamente enquanto herdeiro da tradição crítica frankfurtiana, por outro lado, realiza essa aproximação através da identificação do que seriam deficiências comuns, pois essa herança genuína apenas demonstra limitaçóes do pensamento de Foucault, enquanto Habermas indicaria o caminho a ser desenvolvido a partir da superação da aporia. O que precisa ser investigado é se é possível estabelecer de outra maneira essa vinculação de Foucault com a Escola de Frankfurt, principalmente através da forma como o próprio pensador francês entende sua vinculação a tal tradição de pensamento:

E me parece que a opção filosófica com a qual nos vemos confrontados atualmente é a seguinte. É preciso optar ou por uma filosofia crítica que se apresentará como uma filosofia analítica da verdade em geral, ou por um pensamento crítico que tomará a forma de uma ontologia de nós mesmos,

\footnotetext{
10 Trabalho fundamental também por ter sinalizado para a convergência positiva posteriormente realizada por Honneth (2008), na qual se propóe a reabilitaçáo do potencial da teoria crítica através da psicanálise e em direção ao diagnóstico das patologias sociais, campo de investigação que reuniria todos os pensadores da Escola de Frankfurt, relativizando, assim, a divisão entre círculo interno e círculo externo. Nesse quesito, na esteira de Safatle (2010, p. 88), podemos afirmar que a crítica se converte em sintomatologia que visa a identificar as patologias sociais. Trata-se de um procedimento, diga-se, bastante diferente do realizado em Crítica do Poder, embora ainda continue tentando manter Foucault nitidamente afastado da tradiçấo frankfurtiana, no que tange à análise das sociedades contemporâneas.
} 
de uma ontologia da atualidade. E é essa forma de filosofia que, de Hegel à Escola de Frankfurt, passando por Nietzsche, Max Weber, etc., fundou uma nova forma de reflexáo à que, é claro, eu me vinculo na medida em que posso. (FOUCAULT, 2010, p. 21-22).

Interrogaremos agora a empreitada de Honneth focalizando três eixos: o primeiro concerne à limitação histórica de sua investigação; o segundo diz respeito à identificação problemática entre poder e dominação; o terceiro, à indissociabilidade, em Foucault, entre crítica social e crítica da razáo, o que nos conduz ao tema da "chantagem iluminista".

Honneth perde de vista a reorientação operada no interior do pensamento foucaultiano após 1976, ano de publicação do primeiro volume da História da sexualidade: a vontade de saber. Ora, Foucault opera nesse momento um terceiro deslocamento, para além do poder e do saber, ou seja: para além das matrizes normativas de comportamento e do eixo da formação dos saberes, a questão se estende ao eixo de constituição dos modos de ser do sujeito:

Substituir a história dos conhecimentos pela análise histórica das formas de veridicção, substituir a história das dominações pela análise histórica dos procedimentos de governamentalidade, substituir a teoria do sujeito ou a história da subjetividade pela análise histórica da pragmática de si e das formas que ela adquiriu, eis as diferentes vias de acesso pelas quais procurei precisar um pouco a possibilidade de uma história do que se poderia chamar de "experiências". (FOUCAULT, 2010, p. 7).

Logo, "[...] não é o poder, mas o sujeito, que constitui o tema geral da minha pesquisa”, diz Foucault (2010, p. 274). Nesse período, a noção de experiência como articulação entre formação de saberes, sistemas de poder e formas pelas quais os indivíduos podem e devem se reconhecer, por exemplo, como sujeitos sexuais, é um ponto fundamental desta reorientação que Foucault opera sobre seu próprio pensamento (FOUCAULT, 2006b, p. 193). Contudo, mesmo em trabalhos posteriores, Honneth (2009b) insiste em afastar Foucault das tarefas atuais da teoria crítica e não demonstra preocupação em apreciar essa fase tardia do pensamento foucaultiano ${ }^{11}$.

\footnotetext{
${ }^{11}$ Por exemplo, embora Honneth (2009d, p. 142) reconheça que os dois últimos volumes da História da Sexualidade provocam um redimensionamento no pensamento de Foucault, em especial no que se refere à posição central que a dimensão da subjetividade passa a ocupar na relaçấo entre saber-poder, sustenta que "Foucault concebeu de fato em suas últimas duas obras a subjetividade do homem, já não como mero
} 
Quanto ao que se pode chamar periodo genealógico, muitas das críticas de Honneth procedem, porém, precisam também ser postas à prova diante da fase final do pensamento de Foucault, pois, em nosso entender, está em jogo o valor das reflexôes foucaultianas para a atualização das propostas e formulações da primeira geração da Teoria Crítica.

Dentre as críticas que procedem, podemos destacar o caráter total e inescapável que o poder assume em Foucault, sobretudo em vários trechos de Vigiar e Punir. Uma espécie de "asfixia do poder", segundo as palavras de Muricy (1992, p. 7). Em uma entrevista, Foucault deixa bastante evidente como ele identificou esse problema e procurou contorná-lo:

\begin{abstract}
Tenho, agora, uma visão muito mais clara de tudo isso; acho que é preciso distinguir as relaçóes de poder como jogos estratégicos entre liberdade jogos estratégicos que fazem com que uns tentem determinar a conduta dos outros, ao que os outros tentam responder não deixando sua conduta ser determinada ou determinando em troca a conduta dos outros - e os estados de dominação, que são o que geralmente se chama de poder. E, entre os dois, entre os jogos de poder e os estados de dominação, temos as tecnologias governamentais, dando a esse termo um sentido muito amplo - trata-se tanto da maneira com o que se governa sua mulher, seus filhos, quanto da maneira com que se dirige uma instituição. A análise dessas técnicas é necessária, porque muito frequentemente é através desse tipo de técnica que se estabelecem e se mantém os estados de dominação. Em minha análise do poder, há esses três níveis: as relaçôes estratégicas, as técnicas de governo e os estados de dominação. (FOUCAULT, 2006a, p. 285).
\end{abstract}

Isso sinaliza que a obra de Foucault esteve em constante processo de mutação e também que as críticas oriundas dos representantes da Teoria Crítica, como Habermas, forçaram uma resposta, por exemplo, no que tange ao sentido de poder. E este é um tema no qual, ao que nos parece, a crítica de Honneth a Foucault encontra certos entraves.

O poder, em Foucault, não remete diretamente à dominação ou a um processo de dominaçáo entre duas instâncias que não são de modo algum mediadas. A própria noção de experiência dá conta de como o sujeito ou as formas de subjetivação estão em jogo nas relações de poder-saber. É por isso que há uma diferença entre defender que as relaçóes de poder atravessam todo o

campo de manipulação para as técnicas de poder, senão como elemento independente e constitutivo em uma estrutura de poder respectiva. Seja como for, em suas principais obras sobre a teoria do poder os indivíduos não representam senão seres formáveis e manipuláveis sem oferecer resistência”. 
tecido social e dizer que a sociedade é completamente submetida a um impulso de mais-poder. É a primeira alternativa que Foucault defende explicitamente, em $A$ vontade de saber, postulando o poder como produtivo, positivo e não repressivo; as relações de poder remetendo às estratégias e às resistências. A segunda alternativa é o que Foucault chama de estados de dominação, em que a possibilidade de liberdade é quase completamente obstaculizada.

Assim, ao não levar em conta a fase mais tardia do pensamento de Foucault e ao estabelecer uma identidade entre poder e dominação, isto é, entre relaçóes estratégicas de poder e estados de dominação, a leitura da obra de Foucault realizada por Honneth pode ser questionada, especialmente quanto ao modo de vinculação por ele proposto entre os primeiros frankfurtianos e o pensamento foucaultiano.

Em último lugar, podemos considerar aquilo que Foucault (2008a; 2008b) chama de "chantagem iluminista", ou seja, o argumento segundo o qual seria impossível realizar uma crítica racional da racionalidade, sendo inevitável a alternativa de ser a favor da razáo ou contra a razão, irracionalista, portanto.

Quando Honneth constantemente expóe os supostos avanços realizados pela democracia, é como se essa chantagem motivasse seu argumento, o que, por sua vez, faz com que Foucault passe a ser entendido como alguém, tanto quanto Adorno e Horkheimer, que menospreza os ganhos engendrados pela modernidade, no que diz respeito às liberdades individuais e aos direitos jurídicos. Além de serem vistos como pensadores cuja crítica, devido a sua radicalidade, não se sustenta nem pode garantir seus fundamentos.

Ao recusar aquilo que chama de "chantagem iluminista", Foucault pode afirmar que "[...] as disciplinas reais e corporais constituíram o subsolo das liberdades formais e jurídicas” (FOUCAULT, 2009, p. 209). Quer dizer, a face emancipatória do processo de modernização possui a contraface dos procedimentos de poder. Estes não são um desvio daquele. Nesse sentido, a Razão abstrata, iluminista e libertária constitui a outra face dos processos de sujeição. Ao realizar a crítica dessa maneira, Foucault está claramente na linha de Adorno e Horkheimer, para os quais a reflexão filosófica não pode mais recorrer à Razão abstrata como salvaguarda da emancipação. A crítica se faz enquanto análise imanente de como os efeitos de poder em determinado contexto social são coexistentes aos discursos pretensamente emancipatórios.

Tanto Foucault quanto Adorno e Horkheimer compreendem os processos de sujeiçáo como consequência lógica dos discursos emancipatórios. 
Enquanto Foucault faz isso diretamente com relação ao nascimento das prisóes, Adorno e Horkheimer submetem tal procedimento na análise do fascismo, concebido não como acidente histórico, mas como desenvolvimento cujas bases estão pressupostas na racionalidade instrumental mantida e sofisticada pelo Esclarecimento. Como frisa Matos (1996, p. 22), “[...] o nazismo emblema do mundo administrado - não é um acidente de percurso político, mas o resultado do vitorioso desenvolvimento da ratio, cuja matriz é a ciência moderna”.

A chantagem iluminista quer fazer crer que esse tipo de procedimento conduz a crítica a um beco sem saída, por manter uma aporia insustentável: se a reflexão não pode garantir o fundamento seguro da emancipação, se a Razão é declarada suspeita de coadunação com os efeitos de poder, para que mais a crítica serviria? Ao que ela pode recorrer, para fundamentar seu exercício?

Ao nosso ver, é justamente essa manutenção da condição aporética $d a$ crítica que aproxima Foucault da primeira geração da Escola de Frankfurt. Desse modo, a crítica é menos uma indicação infalível para a práxis e mais um exercício de leitura acerca do presente histórico (GATTI, 2009), com potência de produzir um diagnóstico. Honneth percebeu muito bem isso, embora tenha optado por enfatizar as limitaçôes das ferramentas críticas de Adorno, Horkheimer e Foucault, afirmando que o diagnóstico produzido por esses autores não fornece instrumental adequado para analisar a dinâmica das sociedades contemporâneas.

Contudo, trata-se, em uma palavra, de reposicionar a aporia: não mais a conceber como o beco sem saída da crítica o qual é necessário superar, mas sim enquanto a própria condição de possibilidade do exercício crítico. Desse modo, estamos de pleno acordo com as seguintes palavras:

Com efeito, a preocupação com o fundamento normativo da crítica conduz à recusa de uma radicalizaçáo da crítica, cujo caráter paradoxal se condena. Numa frase, seria este o paradoxo: tornando-se total, visando a própria razáo (problematizando os critérios racionais que servem de normas ao exercício crítico), a crítica anularia a sua pretensão de validade. Ora, neste aspecto, uma insistência nesta preocupaçáo elide o que julgamos ser o âmago de uma crítica filosoficamente radical, a saber, a possibilidade de ela visar as suas próprias condiçôes de possibilidade. Ela será, talvez, paradoxal: mas paradoxal, a bem dizer, já era a crítica como a concebia Kant, em cuja filosofia, mutatis mutandis, a razão comparece paradoxalmente como juíza e ré... (CACHOPO, 2012, p. 53). 
Para nós, por fim, trata-se de enfatizar a radicalidade da crítica desses autores com vistas a destacar a sua atualidade. Nesse sentido, portanto, a obra de Foucault, com efeito, emerge como atualização da crítica social exercida pela primeira geração da Escola de Frankfurt na segunda metade do século XX, mantendo a radicalidade característica a Adorno e Horkheimer.

Hilário, Leomir Cardoso; Cunha, Eduardo Leal. Michel Foucault and the Frankfurt school: reflections on Axel Honneth's The Critique of Power. Trans/Form/Ação, Marília, v. 35, n. 3, p. 157-188, Set./Dez., 2012.

\begin{abstract}
The objective of this paper is to analyze the core elements of Axel Honneth's critique Michel Foucault's thought in The Critique of Power, by linking it with his analysis of the work of the "inner circle" of the Frankfurt school, especially Adorno and Horkheimer. Thus it is understood that Honneth makes an approximation between Foucault's thinking and the Frankfurt School critical tradition, emphasizing common deficiencies that indicate an affiliation between these authors, while at the same time noting their failures in the analysis of contemporary society. Such a reading, despite its innovation in putting side by side Foucault and Habermas as rival developers of critical theory, is limited in not considering the reorientation in Foucault's thought from 1978 on, and in not identifying the notions of power and domination as problematic. These limitations do not preclude sustaining a convergence between Foucault's thinking and that of the Frankfurt school, thinking of it in a positive fashion that is not restricted to the limitations of its critical tools, and instead focusing on the radicality of such criticism, making it possible to highlight its relevance.
\end{abstract}

KEYWORDS: Foucault. Honneth. Frankfurt school. The Critique of Power.

\title{
REFERÊNCIAS
}

ADORNO, Theodor; HORKHEIMER, Max. A Dialética do Esclarecimento: fragmentos filosóficos. Rio de Janeiro: Jorge Zahar, 1985.

ADORNO, Theodor. Dialética negativa. Rio de Janeiro: Jorge Zahar, 2009.

AGAMBEN, Giorgio. Estado de exceção: homo sacer, II, 1. São Paulo: Boitempo, 2007.

CACHOPO, João Pedro. Uma revisão crítica da leitura habermasiana da Dialéctica do iluminismo de Adorno e Horkheimer. Saberes, Natal - RN, v. 1, n. 1, p. 57-70, dez. 2008. 
CACHOPO, João Pedro. Para uma genealogia filosófica da crítica. Imprópria: política e pensamento crítico. Lisboa, no 1, p. 44-56, $1^{\circ}$ sem. 2012.

FOUCAULT, Michel. Verdade e poder. In: A microfísica do poder. Rio de Janeiro: Graal, 2004.

FOUCAULT, Michel. A ética do cuidado de si como prática da liberdade. In: FOUCAULT, Michel; MOTTA, Manoel Barros da. Ética, sexualidade, política. Rio de Janeiro: Forense Universitária, 2006a.

FOUCAULT, Michel. O Uso dos Prazeres e as Técnicas de Si. In: FOUCAULT, Michel; MOTTA, Manoel Barros da. Ética, sexualidade, política. Rio de Janeiro: Forense Universitária, 2006b.

FOUCAULT, Michel. Estruturalismo e Pós-Estruturalismo. In: FOUCAULT, Michel; MOTTA, Manoel Barros da. Arqueologia das ciências e história dos sistemas de pensamento. Rio de Janeiro: Forense Universitária, 2008a.

FOUCAULT, Michel. O que são as Luzes? In: FOUCAULT, Michel; MOTTA, Manoel Barros da. Arqueologia das ciências e história dos sistemas de pensamento. Rio de Janeiro: Forense Universitária, 2008b.

FOUCAULT, Michel. Vigiar e Punir: nascimento da prisão. Ed. 36. Petrópolis: Vozes, 2009.

FOUCAULT, Michel. O Governo de Si e dos Outros: curso no Collège de France (19821983). São Paulo: Martins Fontes, 2010.

GATTI, Lucianno. Thedor W. Adorno: Indústria Cultural e Crítica da Cultura. In: NOBRE, Marcos (Org.). Curso Livre de Teoria Crítica. Campinas: Papirus, 2009.

HABERMAS, Jürgen. Concepçóes de modernidade. Um olhar retrospectivo sobre duas tradiçôes. In A constelação pós-nacional: ensaios políticos. São Paulo: Littera Mundi, 2001, p. 167-198.

HABERMAS, Jürgen. O discurso filosófico da modernidade. São Paulo: Martins Fontes, 2002.

HONNETH, Axel. The critique of power: reflective stages in a critical social theory. 1st MIT Press ed., 1991.

HONNETH, Axel. Teoria Crítica. In: GIDDENS, Anthony; TURNER, Jonathan H. (Org.). Teoria social hoje. São Paulo: UNESP, 1999.

HONNETH, Axel. Honneth esquadrinha "déficit sociológico". Entrevista a Marcos Nobre e Luiz Repa, em 11/10/2003, para a Folha de S. Paulo. 2003a. Disponível em: http://www1. folha.uol.com.br/folha/ilustrada/ult90u37729.shtml. Acesso em: 28 abr. 2011.

HONNETH, Axel. Luta por reconhecimento: a gramática moral dos conflitos sociais. São Paulo: Ed. 34, 2003b. 
HONNETH, Axel. Uma patologia social da razão: sobre o legado intelectual da Teoria Crítica. In: RUSH, Fred. (Org.). Teoria Crítica. Aparecida, São Paulo: Idéias \& Letras, 2008.

HONNETH, Axel. Critica Del Poder: Fases en la reflexión de uma Teoria Crítica de la sociedad. Madrid: Machado, 2009a.

HONNETH, Axel. Patologías de la razón: historia y actualidad de la teoría crítica. Madrid: Katz, 2009b.

HONNETH, Axel. La dinámica social del desprecio. Para determinar la posición de una Teoria Crítica de la sociedad. In: Crítica del agravio moral: patologías de la sociedad contemporánea. Buenos Aires: Fondo de Cultura Económica: Universidade Autónoma Metropolitana, 2009c.

HONNETH, Axel. Foucault y Adorno. Dos formas de una crítica a la modernidad. In: Crítica del agravio moral: patologías de la sociedad contemporánea. Buenos Aires: Fondo de Cultura Económica: Universidade Autónoma Metropolitana, 2009d.

HORKHEIMER, Max. Teoria Tradicional e Teoria Crítica. In: BENJAMIN, Walter; HORKHEIMER, Max; ADORNO, Theodor W.; HABERMAS, Jürgen. Textos escolhidos. São Paulo: Abril Cultural, 1983.

JAY, Martin. A imaginação dialética 25 anos depois. Contemporaneidade e educação: revista semestral de Ciências Sociais e Educação. Rio de Janeiro: IEC, Ano I, n 0 - 1996.

MACHADO, Roberto. Foucault, a ciência e o saber. 3. Ed. Rio de Janeiro: Jorge Zahar, 2006.

MAIA, Antonio Calvacanti. A genealogia de Foucault e a Teoria Critica da Sociedade. 1999, 344 f. Tese (Doutorado em Filosofia) - Pontifícia Universidade Católica, Rio de Janeiro, 1999.

MAIA Antonio Cavalcanti. Foucault e Adorno: Mapeando um campo de Convergências. In: RAGO, Margareth et al. (Org.). Imagens de Foucault: Ressonâncias Nietzschianas. Rio de Janeiro: DP\&A, 2002.

MARCUSE, Herbert. A ideologia da sociedade industrial. 5.ed. Rio de Janeiro, RJ: Zahar, 1979.

MARX, Karl. O capital: crítica da economia política. São Paulo: Nova Cultural, 1988.

MATOS, Olgária. Para que filosofia? In PAIVA, Vanilda. (Org.). Contemporaneidade e educação: revista semestral de Ciências Sociais e Educação. Rio de Janeiro: IEC, Ano I, n $0-1996$.

MURICY, Katia. Apresentação. In: VAZ, Paulo. Um pensamento infame: História e Liberdade em Michel Foucault. Rio de Janeiro: Imago, 1992. 
NOBRE, Marcos. Luta por reconhecimento: Axel Honneth e a Teoria Crítica. In: HONNETH, Axel. Luta por reconhecimento: a gramática moral dos conflitos sociais. São Paulo: Ed. 34, 2003.

NOBRE, Marcos. A Teoria Critica. Rio de Janeiro: Jorge Zahar, 2004.

NOBRE, Marcos. Max Horkheimer: a teoria crítica entre o nazismo e o capitalismo tardio. In: NOBRE, Marcos (Org.). Curso Livre de Teoria Crítica. Campinas, SP: Papirus, 2009.

ROUANET, Sérgio Paulo. As razões do iluminismo. São Paulo: Companhia das Letras, 1987.

SAAVEDRA, Giovani Agostini. A teoria crítica de Axel Honneth. In: SOUZA, Jessé; MATTOS, Patrícia (Org.) Teoria crítica no século XXI. São Paulo: Annablume, 2007.

SAFATLE, Vladimir. A transformação da crítica da razão em análise de patologias do social: o caso Theodor Adorno. In: OLIVEIRA, Cláudio (Org.). Filosofia, psicanálise e sociedade. Rio de Janeiro: Beco do Azougue, 2010. p. 83-96.

SOARES, Jorge Coelho. Escola de Frankfurt: unindo materialismo e psicanálise na construção de uma psicologia social marginal. In: JACO-VILELA, Ana Maria; FERREIRA, Arthur Arruda Leal; PORTUGAL, Francisco Teixeira (Org.). História da psicologia: rumos e percursos. Rio de Janeiro: Nau, 2008.

WERLE, Denilson Luis; MELO, Ruríon Soares. Reconhecimento e justiça na teoria crítica da sociedade em Axel Honneth. In: NOBRE, Marcos (Org.). Curso Livre de Teoria Critica. Campinas, SP: Papirus, 2008.

Recebido em: 02.01.2012

Aceito em: 09.08.2012 